\title{
Atmospheric brown clouds reach the Tibetan Plateau by crossing the Himalayas
}

\author{
Z. L. Lüthi ${ }^{1}$, B. Škerlak ${ }^{2}$, S.-W. Kim ${ }^{3}$, A. Lauer ${ }^{4}$, A. Mues ${ }^{4}$, M. Rupakheti ${ }^{4}$, and S. Kang ${ }^{5,1}$ \\ ${ }^{1}$ Key Laboratory of Tibetan Environment Changes and Land Surface Processes, Institute of Tibetan Plateau Research and \\ CAS Center for Excellence in Tibetan Plateau Earth Sciences, Chinese Academy of Sciences (CAS), Beijing, China \\ ${ }^{2}$ ETH Zurich, Institute for Atmospheric and Climate Science, Zürich, Switzerland \\ ${ }^{3}$ School of Earth and Environmental Sciences, Seoul National University, Seoul, Republic of Korea \\ ${ }^{4}$ IASS Institute for Advanced Sustainability Studies, Potsdam, Germany \\ ${ }^{5}$ State Key Laboratory of Cryospheric Science, Cold and Arid Regions Environmental and Engineering Research Institute, \\ Chinese Academy of Sciences (CAS), Lanzhou, China
}

Correspondence to: Z. L. Lüthi (zoe.luethi@iass-potsdam.de) and S. Kang (shichang.kang@lzb.ac.cn)

Received: 20 August 2014 - Published in Atmos. Chem. Phys. Discuss.: 13 November 2014

Revised: 9 March 2015 - Accepted: 12 April 2015 - Published: 1 June 2015

\begin{abstract}
The Himalayas and the Tibetan Plateau region (HTP), despite being a remote and sparsely populated area, is regularly exposed to polluted air masses with significant amounts of aerosols including black carbon. These dark, light-absorbing particles are known to exert a great melting potential on mountain cryospheric reservoirs through albedo reduction and radiative forcing. This study combines groundbased and satellite remote sensing data to identify a severe aerosol pollution episode observed simultaneously in central Tibet and on the southern side of the Himalayas during 1319 March 2009 (pre-monsoon). Trajectory calculations based on the high-resolution numerical weather prediction model COSMO are used to locate the source regions and study the mechanisms of pollution transport in the complex topography of the HTP. We detail how polluted air masses from an atmospheric brown cloud (ABC) over South Asia reach the Tibetan Plateau within a few days. Lifting and advection of polluted air masses over the great mountain range is enabled by a combination of synoptic-scale and local meteorological processes. During the days prior to the event, winds over the Indo-Gangetic Plain (IGP) are generally weak at lower levels, allowing for accumulation of pollutants and thus the formation of ABCs. The subsequent passing of synopticscale troughs leads to southwesterly flow in the middle troposphere over northern and central India, carrying the polluted air masses across the Himalayas. As the IGP is known to be a hotspot of ABCs, the cross-Himalayan transport of polluted
\end{abstract}

air masses may have serious implications for the cryosphere in the HTP and impact climate on regional to global scales. Since the current study focuses on one particularly strong pollution episode, quantifying the frequency and magnitude of similar events in a climatological study is required to assess the total impact.

\section{Introduction}

The Himalayas and Tibetan Plateau region (HTP), sometimes called the "third pole", contains the largest volume of ice outside the polar regions and impacts radiative budgets and climate (Ye and Wu, 1998; Ma et al., 2009). Recently, a growing body of research has demonstrated that the atmosphere and cryosphere in the HTP are undergoing extraordinary changes, including atmospheric warming (Gautam et al., 2010; Thompson et al., 2000; Kang et al., 2010) and in many parts rapid glacier melting (Bolch et al., 2012; Yao et al., 2012). Consequently, the seasonal water availability of important Asian river systems are very likely to be affected (Immerzeel et al., 2010; Kehrwald et al., 2008). In addition to greenhouse gases, increasing ambient concentrations of black carbon (BC) appear to be an anthropogenic driving force of the observed changes in these remote regions (Lau et al., 2010; Ramanathan and Carmichael, 2008). Lightabsorbing aerosol particles such as mineral dust and BC con- 
tribute to the atmospheric heating and the albedo reduction once deposited on glaciers. Albeit only contributing a few percent to the total aerosol mass, $\mathrm{BC}$ exerts major radiative effects (Bond et al., 2013; Jacobson, 2001), especially over the HTP during pre-monsoon seasons when the solar radiative flux at the surface is very high (Flanner et al., 2007).

Even though background air pollution levels in the HTP are very low, recurring pre-monsoonal $\mathrm{BC}$ peaks have been documented at high altitudes of the south-facing Himalayan slopes (e.g., Marinoni et al., 2010, 2013; Decesari et al., 2010) which are sometimes directly exposed to atmospheric brown clouds (ABC) (Ramanathan et al., 2007b; Bonasoni et al., 2010). Brown clouds have been defined as "huge blankets or layers of haze generally composed of lightabsorbing submicrometer-sized carbonaceous aerosol particles" (Engling and Gelencser, 2010). Areas that are particularly affected by brown clouds, so-called ABC hotspots, are characterized by an anthropogenic aerosol optical depth (AOD) larger than 0.3 and an absorbing aerosol optical depth (AAOD) greater than 0.03 for at least one season (Ramanathan et al., 2007a). Such conditions are frequently observed on the southern side of the Himalayas, especially over the Indo-Gangetic Plain (IGP) during the dry months (November to May). BC transported from this regional hotspot might thus contribute to the retreat of Himalayan glaciers (Engling and Gelencser, 2010). Furthermore, recent studies show BC observations on snow and in ice even further north on the Tibetan Plateau (TP) (e.g., Xu et al., 2009; Qian et al., 2011; Ming et al., 2013; Kaspari et al., 2011) and springtime episodes with large amounts of pollutants observed on the TP have been reported (Engling et al., 2011; Xia et al., 2011). As a consequence of such episodes, BC concentrations on glaciers could significantly increase on the TP and affect the surface albedo (Zhao et al., 2013).

Recent GEOS-Chem and HYSPLIT model calculations of $\mathrm{BC}$ advection to the TP suggest that the dominant source regions depend on season and receptor location, but South and East Asia show the highest overall contribution (Kopacz et al., 2011; Lu et al., 2012). However, to date, the mechanisms of pollutant transport from the ABC hotspot in the IGP and from the foothills of the Himalayas to the TP have not been investigated in detail. One reason for the limited knowledge about aerosol pollution on the HTP is the small number of long-term in situ observations. In addition, the results from chemistry transport models still have large uncertainties due to the complex terrain and the specific meteorological conditions, as do the emission data sets that are used for modeling (Fleming et al., 2012). A widespread hypothesis (see e.g., Cao et al., 2011) suggests that the high altitude of the Himalayas acts as a physical barrier inhibiting the transport of $\mathrm{BC}$ across the mountains onto the TP with the exception of deep river valleys that cut across the mountain range and provide a pathway for pollutant transport.

The present work addresses the mechanisms and pathways of cross-Himalayan pollution transport that occurs over large areas under specific meteorological conditions. We base the analysis on a pollution event in March 2009 that can be identified from ground-based and space-borne remote sensing data (Sect. 3.1). We present trajectory calculations and an analysis of the meteorological situation using a regional high-resolution numerical weather prediction model (Sect. 3.2). The goals of this study are (1) to investigate whether major pollution episodes identified on the TP set in synchronously with pollution episodes measured at the southern face of the Himalayas, (2) to determine if "plumes" of air pollution observed on the TP originate at the southern side of the Himalayas, (3) to determine whether ABCs measured at the southern side of the Himalayas can traverse the high mountain range not only through the major northsouth river valleys but also by being lifted and advected over the Greater Himalayas and (4) to understand which local and synoptic-scale meteorological phenomena enable the transport across the Himalayas.

Overall, this study seeks to improve the understanding of the intensely discussed cross-Himalayan pollution transport and its effect on cryosphere and climate in the context of raising anthropogenic emissions in Asia.

\section{Methods and data}

We describe the data obtained from ground-based and satellite remote sensing measurements in Sect. 2.1 and 2.2, respectively. In Sect. 2.3 we elaborate on the setup of the numerical weather prediction model used for the trajectory calculations.

\subsection{Ground-based data}

The identification of aerosol pollution events in the HTP is based on quality-assured data from the Aerosol Robotic Network (AERONET) (Holben et al., 1998). AERONET provides globally distributed observations of spectral AOD, inversion products and the amount of precipitable water. Complete descriptions of the sun-sky scanning spectral radiometer instruments, measurement sequences, uncertainties and cloud screening procedures can be found in the literature (e.g., Eck et al., 1999; Dubovik and King, 2000; Smirnov et al., 2000). In this study, only data sets that have the lowest possible uncertainties in unpolluted regions are used. We therefore do not include spectral refractive indices and single-scattering albedo from almucantar scans with AOD $(440 \mathrm{~nm})<0.4$ to ensure sufficient sensitivity to aerosol absorption (Dubovik et al., 2000). The Spectral Deconvolution Algorithm (SDA) version 2, level 2.0, which is applied in this study, uses optical principles to distinguish the sub-micron fine-mode AOD (hereafter FMF) from the super-micron coarse-mode AOD at a standard wavelength of 500 nm (O'Neill, 2003; O'Neill et al., 2008). 

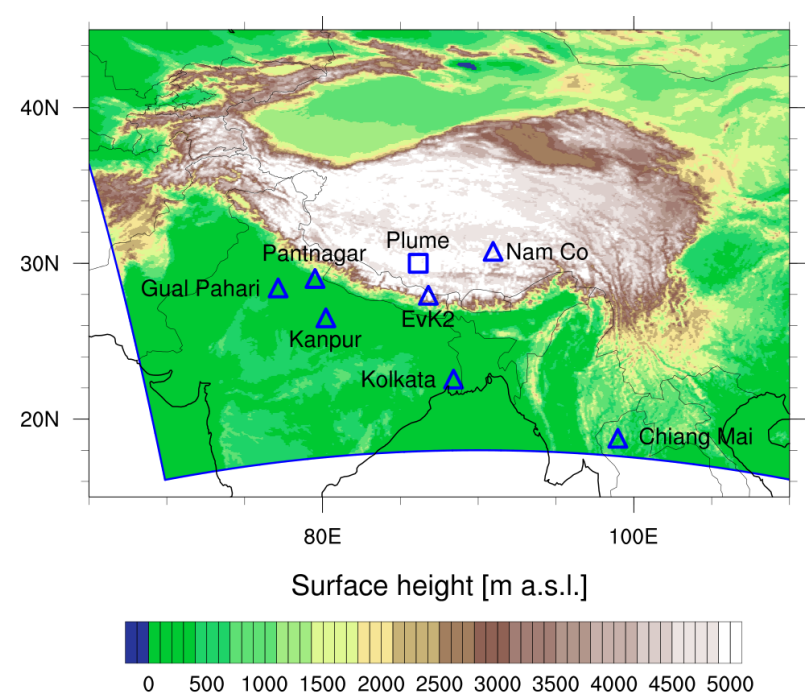

Figure 1. Topography of the Indian subcontinent and the Tibetan Plateau in COSMO. Blue triangles indicate the AERONET stations used in this study and the blue square shows the observed location of a pollution plume.

Here, FMF is taken as a proxy for polluted air since anthropogenic aerosol optical thickness is dominated by fine aerosols, while natural aerosols contain a substantial fraction of coarse aerosols. Typically, the radius of these coarse particles such as mineral dust and sea salt is $>1 \mu \mathrm{m}$ as they are being generated mechanically, while combustion-produced particles including open burning, biofuel use and industrial pollution are predominately fine-mode particles with a radius of $<1 \mu \mathrm{m}$ (Eck et al., 2010).

The two main HTP reference stations used in this study are Nam Co Monitoring and Research Station for Multisphere Interactions (Nam Co), situated in central Tibet (30.77 $\mathrm{N}, 90.96^{\circ} \mathrm{E}, 4730$ ma.s.1.), and EvK2-CNR Nepal Climate Observatory-Pyramid (EvK2) located at the southern face of the Greater Himalayas $\left(27.95^{\circ} \mathrm{N}, 86.81^{\circ} \mathrm{E}\right.$, 5050 ma.s.1.). Both stations are shown in Fig. 1. At Nam Co, over 680 days of level 2 SDA data were available at the time of this study, covering the years 2006-2012. This site is a representative background station and currently the only AERONET site with long-term L2 data sets in central Tibet. Nam Co is thus well suited to assess the extent and effect of long-range transport of pollution to inland Tibet (Xia et al., 2011; Cong, 2009). Data sets from additional AERONET sites (see Fig. 1) with level 2 SDA data available for the time period of the most severe pollution event are used in order to examine the spatial extent of the polluted air mass. We define pollution events as periods with at least five days showing high FMF (i.e., daily means that lie above the 75th percentile) simultaneously at Nam Co and at EvK2. Details about the AERONET stations are presented at http://aeronet.gsfc.nasa.gov, from which all quality assured data have been downloaded.

\subsection{Satellite data}

Cloud-Aerosol Lidar with Orthogonal Polarization (CALIOP) is a two-wavelength polarization-sensitive lidar on board the Cloud-Aerosol Lidar and Infrared Pathfinder Satellite Observation (CALIPSO) satellite. Its data sets provide high-resolution vertical profiles of aerosols and clouds at a 16-day revisiting time. Nighttime profiles show lower background noise, which is an advantage when analyzing pollution aerosols in remote areas such as the HTP; as for most lidars, daylight acts as a disturbance to the signal returns and hence reduces the signal-to-noise ratio, with the consequence that CALIPSO's nighttime data have a superior quality to the daytime data (Marenco et al., 2014). Detailed information about the instrument, data resolution, measurement techniques and final products are given by Winker et al. (2009). For this study, we selected nighttime profiles upwind of the HTP AERONET stations during the pollution event in order to analyze the vertical extension of polluted air masses that are transported towards the HTP. The products used in this study include the following data sets: level 1B total (parallel and perpendicular) attenuated backscatter $\left(\mathrm{km}^{-1} \mathrm{sr}^{-1}\right)$ shown in color-modulated, altitudetime images at $532 \mathrm{~nm}$; lidar level 2 Vertical Feature Mask which distinguishes between clouds and aerosols based on the Cloud Aerosol Discrimination function; and an aerosol subtype identification based on the Scene Classification Algorithm, which is also a level 2 product (Winker et al., 2009).

AAOD is calculated with the near-UV OMAERUV algorithm for measurements by the Ozone Monitoring Instrument (OMI) aboard the Aura satellite (Torres et al., 2007). This AAOD $500 \mathrm{~nm}$ data set is used in this study to compare the light-absorbing aerosol distribution over southern Asia during the analyzed pollution event and during a "cleaner" period over the HTP and over the IGP.

\subsection{Model setup and trajectory calculations}

Due to the complex topography of the HTP, a detailed analysis of the history of polluted air masses requires high-resolution meteorological fields. To this end, we performed a 7-day simulation with the non-hydrostatic numerical weather prediction model COSMO (Baldauf et al., 2011) from 00:00 UTC on 10 March 2009 to 00:00 UTC on 17 March 2009. The model was run at a horizontal resolution of $7 \mathrm{~km}\left(0.0625^{\circ}\right.$, rotated grid $)$ and with 79 vertical levels from the surface up to $15 \mathrm{hPa}$. The internal model time step is $40 \mathrm{~s}$ and meteorological fields are written to disk every hour. COSMO is driven by operational analyses from the European Centre for Medium-Range Weather Forecasts (ECMWF, 0.5 ${ }^{\circ}$ horizontal resolution and 91 vertical levels) which are used to update the boundary conditions every $6 \mathrm{~h}$.

Kinematic backward and forward trajectories were calculated using the Lagrangian Analysis Tool LAGRANTO 

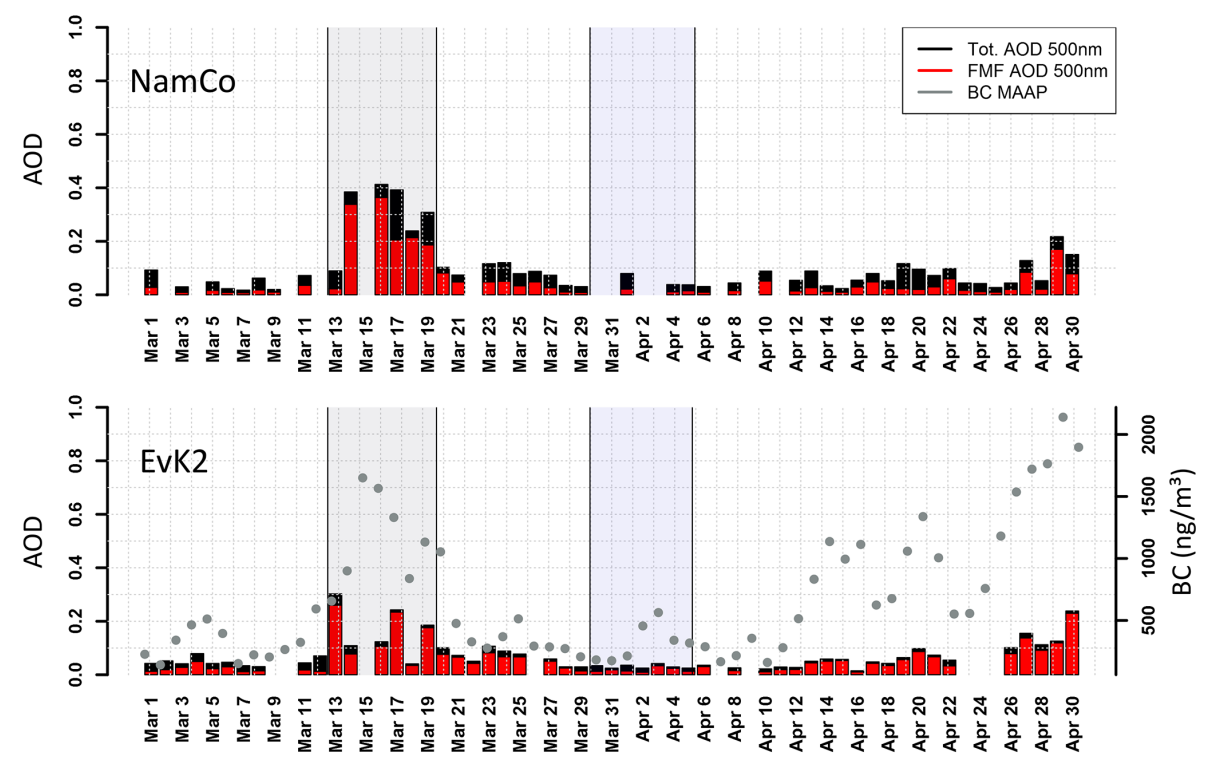

Figure 2. AERONET AOD time series. Red bars indicate the fine-mode fraction (FMF) of the total aerosol optical depth (AOD) at $500 \mathrm{~nm}$ (black columns). Gray circles indicate black carbon measurements from Multi-Angle Absorption Photometer (MAAP) at EvK2. The pollution event analyzed in this study (13-19 March 2009) is highlighted in gray and the cleaner period (30 March-5 April 2009) is highlighted in blue. Blank dates indicate missing data.

(Wernli and Davies, 1997), which applies an iterative Eulerian integration scheme (three steps) to the hourly wind fields from COSMO. Two ensembles of trajectories were started in this study: the first one ( $48 \mathrm{~h}$ backward and forward) at 21:00 UTC on 13 March 2009 over an aerosol-rich air mass in Tibet and the second one (72 $\mathrm{h}$ backward at 03:00 UTC on 16 March 2009) over Nam Co station. In both cases, we started trajectories from a regular grid in longitude and latitude (11 grid points in both directions) at height levels from the surface to $2000 \mathrm{~m}$ above ground in steps of $100 \mathrm{~m} \mathrm{(121}$ trajectories for every level). All trajectories are started at a horizontal distance of less than $60 \mathrm{~km}$ from the region of interest. This ensemble of trajectories is used to quantify the relative contributions of different pathways and allows to assess the sensitivity to trajectory starting location and height. Meteorological parameters such as temperature and water vapor mixing ratio from COSMO output are temporally and spatially interpolated to the trajectory location.

In addition to the ECMWF analyses, we use the reanalysis data set ERA-Interim (Dee et al., 2011) for the averages presented in Sect. 3.1.2. The meteorological fields from ERAInterim are interpolated from a spectral resolution of T255 to a regular grid with $1^{\circ}$ horizontal resolution and 60 vertical levels.

\section{Results and discussion}

In this section, detailed analysis is presented for the pollution episode during 13-19 March 2009, which was identified as the most severe event in the data set, showing the high- est amounts of anthropogenic aerosol at Nam Co in 2009 and simultaneously very high pollution levels at EvK2. This episode has been identified by analyzing AERONET time series and comparing them to $\mathrm{BC}$ observational data from sites in the HTP (Sect. 3.1.1) and to OMI AAOD data in the IGP (Sect. 3.1.2), which allows the assessment of the ABC extension. A particular pollution feature ("plume") is identified from a CALIOP vertical cross section from the IGP to inland Tibet (Sect. 3.1.3). The meteorological conditions that favor the formation of severe air pollution and the long-range transport onto the HTP are then analyzed in Sect. 3.2. Using COSMO, $48 \mathrm{~h}$ backward and forward trajectories are calculated to determine whether this plume originated south of the Himalayas and was carried towards Nam Co (Sect. 3.2.1). Furthermore, $72 \mathrm{~h}$ back-trajectories started near Nam Co on the day with greatest observed FMF demonstrate how ABCs can cross the Himalayas (Sect. 3.2.2).

\subsection{Case study selection}

\subsubsection{Measurements in the HTP}

Complete 24 months of AERONET L2 measurements at Nam Co (cf. Fig. 1) are only available for the years 2009 and 2010. These measurements show episodes of significant fine-mode aerosol contribution to total AOD $500 \mathrm{~nm}$ during the pre-monsoon months. Interestingly, the most remarkable episodes are found to occur synchronously with high FMF observations at EvK2. The FMF AOD $500 \mathrm{~nm}$ is typically associated with pollution aerosols that mainly consist of particles in the sub-micron fraction (cf. Sect. 2.1). Over the course 


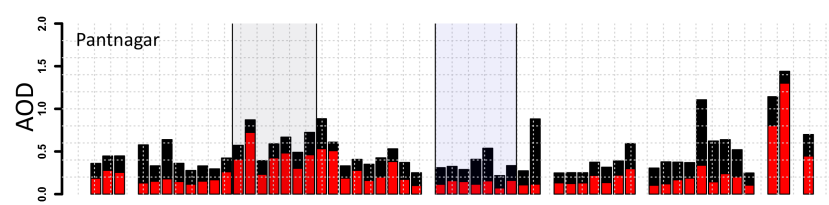

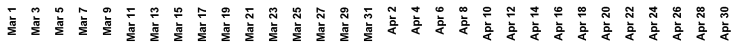
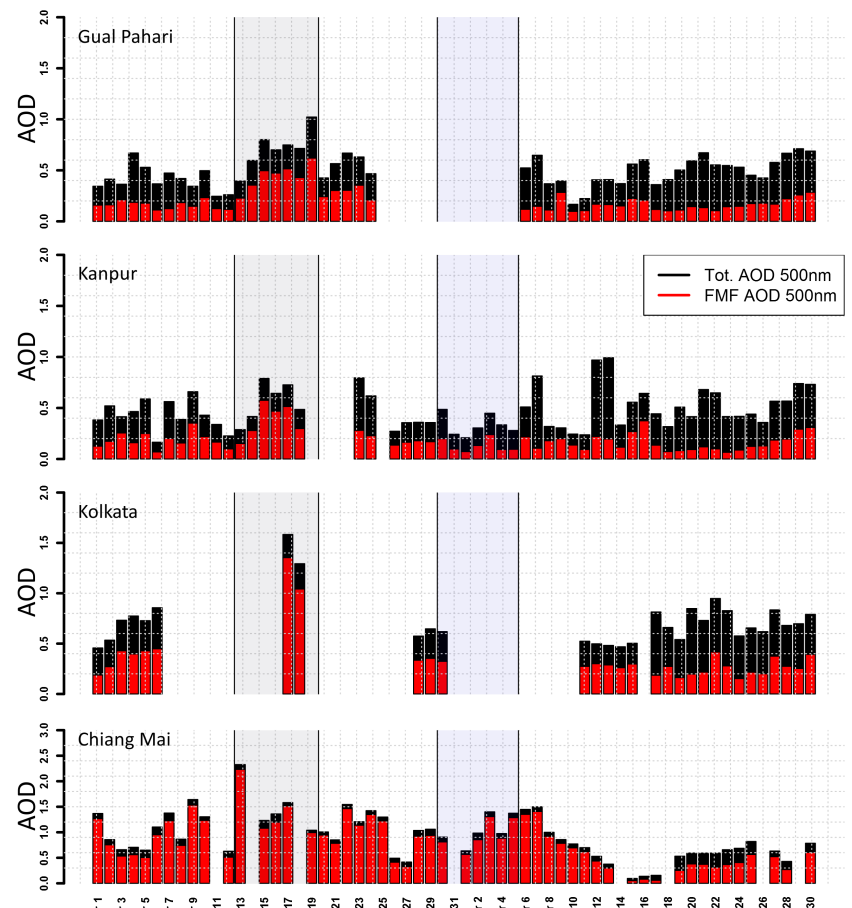

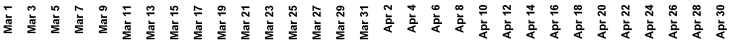

Figure 3. As Fig. 2 but for AERONET stations in the IGP and Thailand.

of 2009 and 2010, eight cross-Himalayan pollution events were identified during the months of March, April and May. Here, we present details of the most severe pollution episode that occurred during 13-19 March 2009. This event shows an average FMF at Nam Co of 0.22 while the means of the remaining seven events range from 0.03 to 0.07 (see Fig. 2).

The AERONET fine-mode AOD $(500 \mathrm{~nm})$ and the total AOD $(500 \mathrm{~nm})$ for Nam Co and EvK2 during March and April 2009 (Fig. 2) suggest an increase of FMF in mid-March (gray bar) and a subsequent cleaner period in the end of March (blue bar). A sudden rise in FMF occurred at EvK2 on 13 March 2009 and 1 day later at Nam Co. The pollution levels at the two HTP stations stayed elevated until 19 March 2009. No AERONET aerosol data were available for 15 March 2009, which was an overcast day.

The maximum FMF $(500 \mathrm{~nm})$ at Nam Co peaked at 0.38 on 16 March 2009. This is consistent with the findings of Xia et al. (2011) who reported that the total AOD $500 \mathrm{~nm}$ at Nam Co was at its maximum on this day with a value of $0.42,1$ order of magnitude above average conditions at this station (annual baseline $=0.029$ ). In Sect. 3.2, we present details of the involved pollution transport pathways based on high-resolution trajectory calculations started on the days with very high FMF at Nam Co, i.e., 14 and 16 March 2009.

In order to further support the association of FMF with pollution aerosols and in particular with absorbing aerosols, we compare the AERONET data with available in situ BC concentrations. The BC data were retrieved from MultiAngle Absorption Photometer measurements and from filter analyses at EvK2 and Nam Co, respectively. The circles in Fig. 2 show a high temporal correlation of $\mathrm{BC}$ concentrations with the FMF at EvK2. Elevated concentrations of BC and FMF at EvK2 were retrieved during the 13-19 March event and also during the second half of April 2009. It is interesting to note that the $\mathrm{BC}$-to-FMF ratios differ between these events, possibly caused by varying aerosol type contributions to the polluted air masses reaching the measurement site. Continuous BC measurements at Nam Co station are only available since late 2010 (M. Jing, personal communication, 20 November 2013) but a recent study on total suspended particulate matter by Zhao et al. (2013) points out that a sudden increase of carbonaceous aerosols, i.e., organic carbon and black carbon, also occurred in midMarch 2009 (not shown). These in situ data suggest that this pre-monsoon aerosol event consisted of significant pollution which reached central Tibet not only at elevated levels but also at the surface.

\subsubsection{Measurements in the IGP}

A significant build-up of air pollution during the 1319 March 2009 event was also observed at stations in the IGP and in northern Thailand. Measurements of AERONET sites with available L2 data during the case study are shown in Fig. 3 (see Fig. 1 for the location of the stations). Interestingly, compared to data from EvK2 shown in Fig. 2, the AERONET measurements from the IGP show a relatively large contribution of coarse-mode particles to the total AOD $500 \mathrm{~nm}$, which is mostly associated with wind-blown dust. This is in line with the results of Prabha et al. (2012), Gautam et al. (2011) and Dey and Di Girolamo (2010), who have recently reported a larger contribution of dust aerosols to total AOD over the IGP compared to the southern slope of the Himalayas, where fine-mode anthropogenic pollution aerosols play a dominant role during pre-monsoon. Yet, it is important to bear in mind that a significantly increasing trend of anthropogenic aerosols has been identified in data of the AERONET Ångström exponent over India, especially during December to March (Babu et al., 2013). This implies an increase in air pollution over the IGP during the past years.

Overall, the AERONET data sets in Figs. 2 and 3 suggest the occurrence of an $\mathrm{ABC}$ over South Asia that extends as far as the HTP. This is supported by the significant (nearly total) FMF contribution to the total AOD $500 \mathrm{~nm}$ at EvK2 station. A direct exposure of the station to $\mathrm{ABCs}$ has recently been analyzed in numerous studies based on comprehensive data sets from this high-altitude atmospheric monitoring site (e.g., 


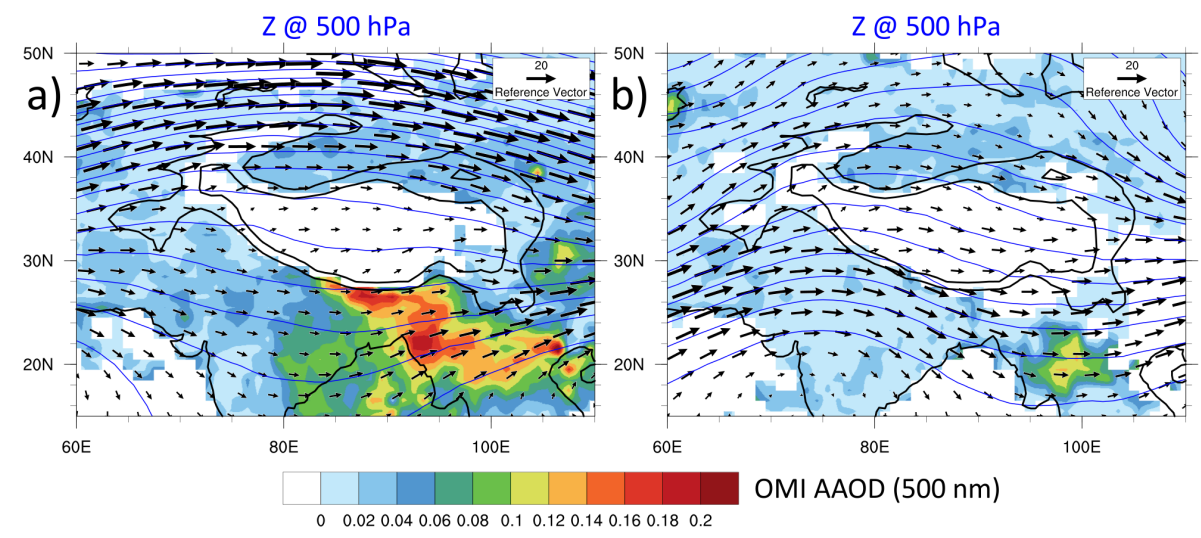

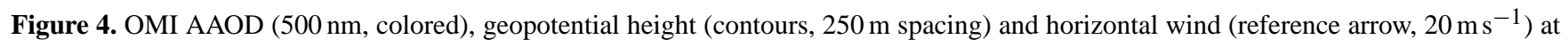
$500 \mathrm{hPa}$ from ERA-Interim averaged over (a) the pollution event 13-19 March 2009 and (b) a cleaner 7-day period between 30 March and 5 April 2009 (cf. Fig. 2).

Bonasoni et al., 2010; Decesari et al., 2010; Marinoni et al., 2013).

The high contribution of absorbing aerosols to the total AOD during the 13-19 March 2009 pollution event is shown in Fig. 4a (OMI AAOD $500 \mathrm{~nm}$ ). For comparison, Fig. 4b depicts the spatial distribution of AAOD during a "cleaner" 7-day period (30 March to 5 April 2009, cf. Figs. 2 and 3) in the region surrounding the HTP. The dense haze extending southwest of the HTP displayed in Fig. 4a suggests the occurrence of an $\mathrm{ABC}$ with a significant amount of absorbing aerosols along the foothills of the Himalayas. The HTP region, however, appears as a blank area in Fig. 4. This is due to the fact that the satellite-derived AAOD data are very limited for the HTP as a consequence of its high surface reflectance.

The combination of ground- and space-based remote sensing data suggests the presence of an $\mathrm{ABC}$ with AERONET AOD $>0.3$ and OMI AAOD $>0.03$ that were observed not only south of the great mountains or in the Himalayan valleys but also on the TP.

\subsubsection{Air pollution feature on the TP}

Several CALIOP transects that were retrieved over the past years were found to show significant extensions of pollution plumes "coating" the HTP. This indicates that the polluted air masses do not only accumulate in the valleys but can also cover large areas in this usually pristine region.

In Fig. 5 we show the CALIOP transect retrieved upstream of Nam Co station at 20:35 UTC on 13 March 2009 during the onset of the pollution event analyzed in this study. Thin cirrus clouds can be seen at about $10 \mathrm{~km}$ (yellow to gray). A dense layer of aerosols extending over a vast area from India and Nepal to the TP, where it reaches elevations of 6$7 \mathrm{kma.s.1.,}$ is visible in the lidar backscatter data (Fig. 5a) and in the Cloud Aerosol Discrimination output (Fig. 5b). The aerosol layer over southern TP (red circle, hereafter referred to as "plume") was identified as air pollution by the CALIPSO aerosol subtype classification (see Sect. 2.2), and more specifically as carbonaceous particles or smoke aerosols (Fig. 5c).

\subsection{Source regions and transport mechanisms}

In this section, we identify the source regions and involved transport mechanisms of two major pollution features observed over the TP during the March 2009 event: (1) the pollution "plume" retrieved by CALIOP (cf. Sect. 3.1.3) during the overpass of CALIPSO which was closest in time and distance upwind from Nam Co station on 13 March 2009 and (2) the highest daily FMF at Nam Co on 16 March 2009 (cf. Sect. 3.1.1).

For both cases, we identify three transport pathways of air (hereafter referred to as "air streams") arriving at the plume region and Nam Co from trajectories started near these locations.

\subsubsection{Plume}

In order to investigate how this plume (cf. Fig. 5) reached the TP and where the polluted air was advected to, we calculate $48 \mathrm{~h}$ backward and forward trajectories (see Sect. 2.3) starting at 21:00 UTC on 13 March 2009 in the vicinity of the observed plume $\left(30.00^{\circ} \mathrm{N}, 86.15^{\circ} \mathrm{E}\right)$. Here, we show the trajectories started near the surface at 5510 ma.s.l. (see Fig. 6).

Three major source regions can be identified (see Fig. 6b). A large fraction of the trajectories is advected over the Himalayas from the southwest and stays at approximately constant altitude. We refer to these trajectories as "air stream 1" (blue lines in Fig. 6b) if they stay above 5500 ma.s.1. over the IGP and as "air stream 2" (green) otherwise. "Air stream 3" (orange) consists of trajectories that originate over the TP and cross the Himalayas from north to south before being lifted onto the TP again. Out of the 121 trajectories 


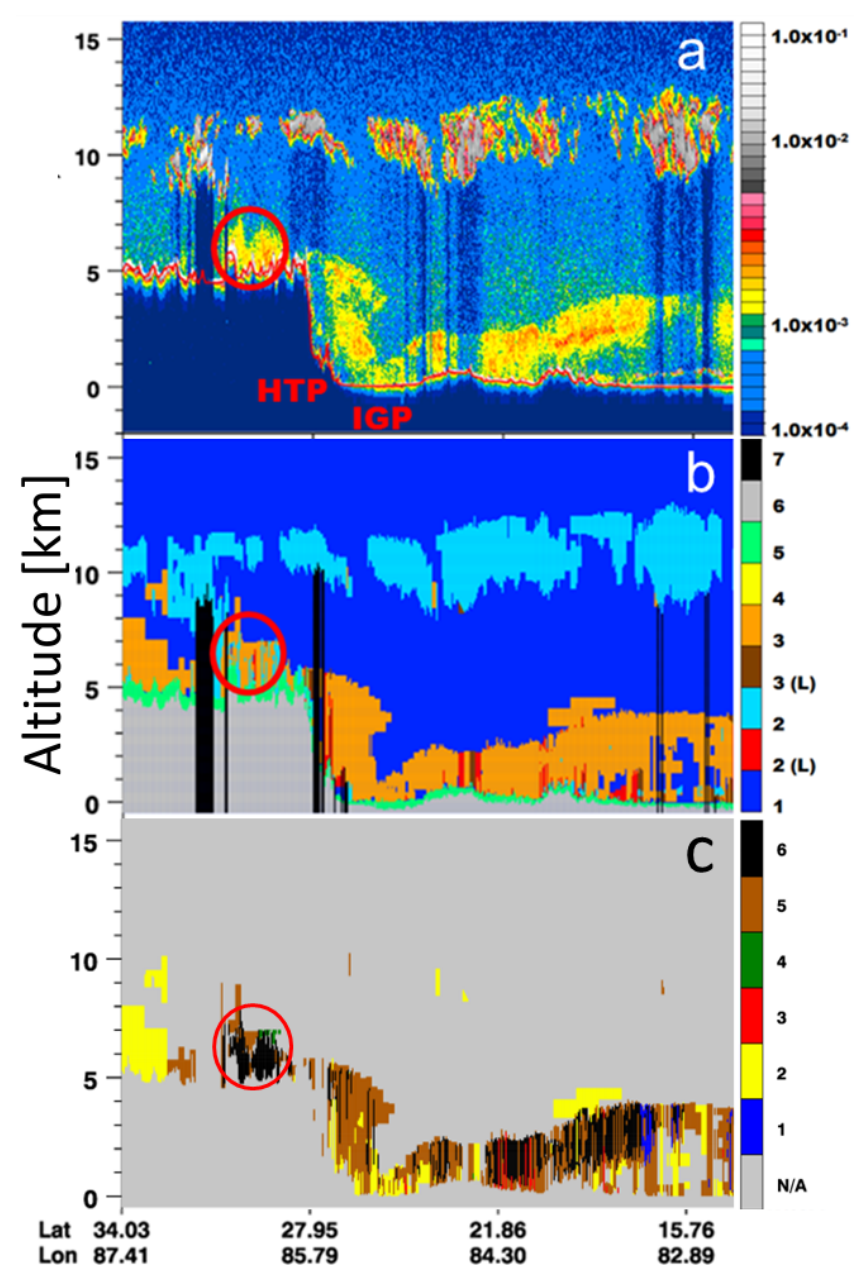

Figure 5. (a) CALIOP vertical profile at 20:30 UTC on 13 March 2009 showing the color-coded total attenuated backscatter lidar return signal at $532 \mathrm{~nm}$ with green, yellow and red indicating aerosols at low, medium and high concentrations, respectively; (b) cloud-aerosol output, with 1 clear air, 2 cloud, 3 aerosol, 4 stratospheric layer, 5 surface, 6 subsurface and 7 totally attenuated; (c) aerosol subtype profiles with 1 clean marine, 2 dust, 3 polluted continental, 4 clean continental, 5 polluted dust and 6 smoke. Red circles mark the plume over the TP.

started at 5510 ma.s.1., 117 (97\%) fall into one of these three categories. The three air streams contribute approximately equally to the air in the vicinity of the observed aerosol plume with 36, 43 and 38 trajectories in air streams 1, 2 and 3, respectively. Air stream 3 was found to only contribute to nearsurface air at the plume location whereas air streams 1 and 2 also appear in all backward trajectory calculations started at higher levels (not shown).

The temporal evolution of height, water vapor $\left(Q_{\mathrm{v}}\right)$, potential temperature $(\theta)$ and equivalent potential temperature $\left(\theta_{\mathrm{e}}\right)$ along the trajectories is shown in Fig. 7. The trajectories show that air streams 1 and 2 stay roughly at constant altitude (around $5500 \mathrm{~m}$ a.s.l.) throughout $12 \mathrm{March}$. Therefore, the advection can be estimated from the synoptic situation at $500 \mathrm{hPa}$. As can be seen from the geopotential height at $500 \mathrm{hPa}$ shown in Fig. 8, the westerly (northwesterly) winds over northern (northeastern) India at mid-tropospheric levels are associated with a ridge over India. These winds obtain an increasing southerly component on 13 March as the ridge moves eastwards followed by another trough. This results in a southwesterly flow over large parts of northern India. As air streams 1 and 2 are advected towards the Himalayas quasiisentropically on slanting isentropes, they rise approximately $1000 \mathrm{~m}$ when crossing the Himalayas (cf. Figs. 6a and 7).

All trajectories enter the PBL over the TP in the afternoon of 13 March (Fig. 7). As a consequence, water vapor content rises abruptly to values around $1 \mathrm{~g} \mathrm{~kg}^{-1}$, which is also reflected in an increase of $\theta_{\mathrm{e}}$. Away from the TP, potential temperature decreases with a rate of approximately $1 \mathrm{Kday}^{-1}$ which is typical for radiative cooling of the free troposphere. Over the plateau, however, a strong decrease in $\theta$ from 316 to $312 \mathrm{~K}$ in $12 \mathrm{~h}$ can be seen as the trajectories within the PBL over the TP are affected by radiative cooling of the surface during nighttime. Note that no diurnal cycle is visible in $\theta$ and $\theta_{\mathrm{e}}$ on 12 March for trajectories in the free troposphere.

Air stream 3 descends from the TP on 12 March on the western side of the passing trough (see Figs. 6 and 8 ) to the southern side of the Himalayas. There, the air is first advected eastwards in the afternoon of 12 March before returning to west Nepal during the following night. This is consistent with the zonal winds along the southern face of the Himalayas at $850 \mathrm{hPa}$ shown in Fig. 9 that change from westerlies on 12 March to easterlies on 13 March as the new trough discussed above is approaching. During the night, vertical mixing is much weaker and valley wind systems seem to play an important role. At the southeastern corner of the TP, the prevailing northerly winds on the rear side of the passing trough are channeled by the Brahmaputra valley as they descend. Thus, even though winds at $500 \mathrm{hPa}$ are still westerly, easterlies at lower levels prevail over much of the IGP (see bottom panel in Fig. 9).

With the Himalayan flanks heating up during daytime on 13 March, air stream 3 rises approximately $2000 \mathrm{~m}$ within $10 \mathrm{~h}$. As this air stream has been in contact with the PBL (or at least very near to its top) over the TP and the IGP, it is affected by the diurnal temperature cycle of the near-surface air temperature, which can be seen in the temporal evolution of $\theta$ and $\theta_{\mathrm{e}}$ along the trajectories and the elevated values of $Q_{\mathrm{v}}$. On average, the potential temperature rises around $3 \mathrm{~K}$ on 12 March when most of the trajectories are above the $\mathrm{TP}$ and around $5 \mathrm{~K}$ as they ascend across the Himalayas on 13 March.

The high PBL and the strong updrafts near the surface associated with the heated mountain flanks can be seen in a cross section along the main flow direction (thick black line segment in Fig. 6b) at 09:00 UTC on 13 March 2009 (Fig. 10). While air streams 1 and 2 (blue and green squares, respectively) cross the Himalayas quasi-isentropically at ap- 

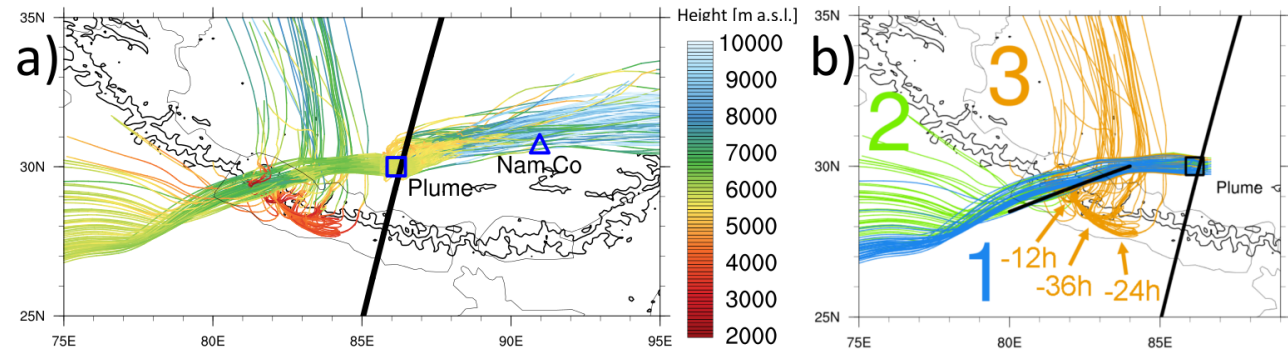

Figure 6. Trajectories ( $48 \mathrm{~h}$ backward and forward) started near the observed high aerosol concentrations ("Plume", square) at 21:00 UTC on 13 March 2009 from an altitude of $5510 \mathrm{~m}$ a.s.l. Black lines show the orography (2000 and $4000 \mathrm{ma}$ a.s.l. contour lines), the blue triangle is Nam Co station and the thick solid black line shows the CALIOP transect. (a) Height along the trajectories, color coded (in ma.s.1.); (b) backtrajectories classified into three air streams: (1) trajectories above $5500 \mathrm{~m}$ a.s.l. over the IGP, (2) below this height and (3) originating over the TP. The approximate location of air stream 3 is indicated for 12, 24 and $36 \mathrm{~h}$ prior to reaching the plume location. The black line segment indicates the cross section shown in Fig. 10.
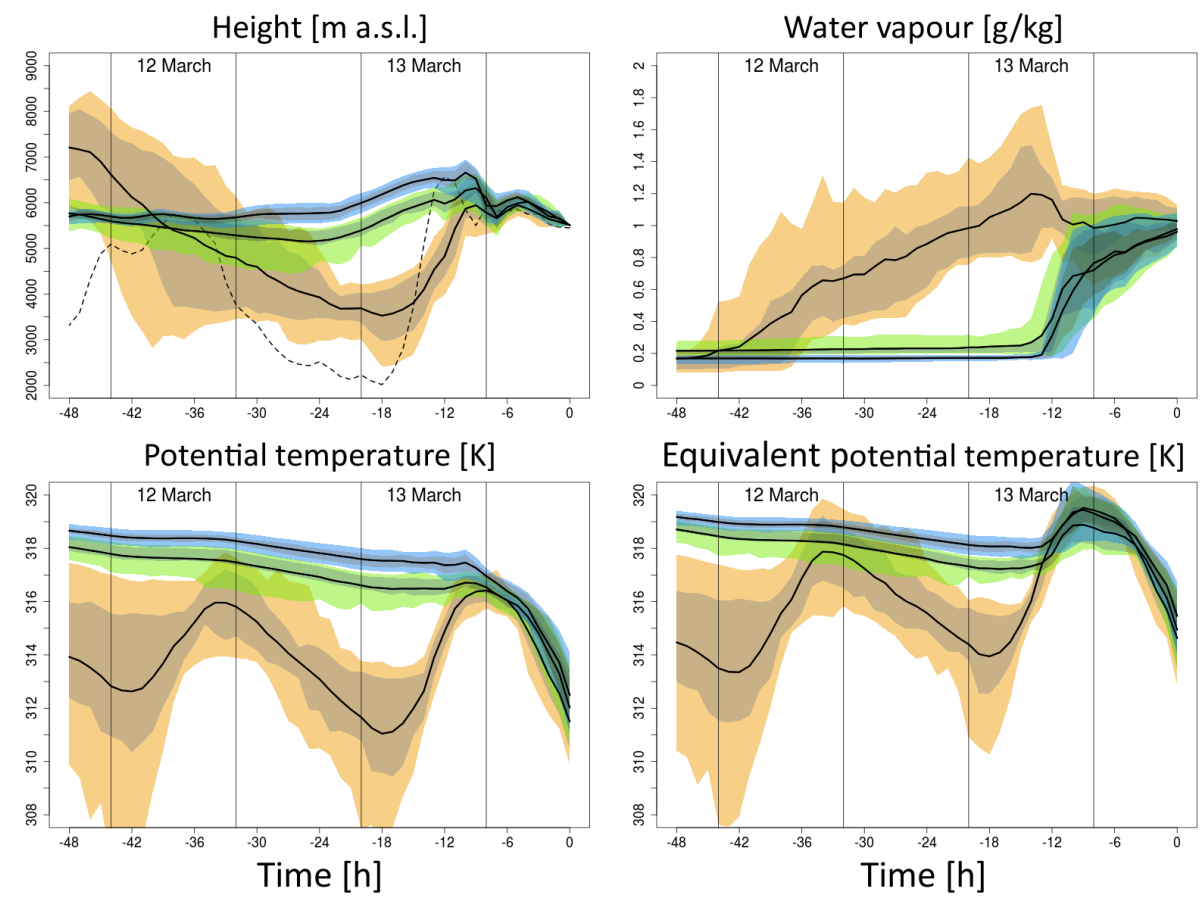

Figure 7. Temporal evolution of height, water vapor $\left(Q_{\mathrm{V}}\right)$, potential temperature $(\theta)$ and equivalent potential temperature $\left(\theta_{\mathrm{e}}\right)$ for the $48 \mathrm{~h}$ backward trajectories started at 21:00 UTC on 13 March 2009 near the plume location at $5510 \mathrm{ma}$.s.l. Blue, green and orange colors show air streams 1, 2 and 3, respectively (cf. Fig. 6b). Black lines show median values at every time step and the shading indicates 10, 25, 75 and 90 percentiles (total of 121 trajectories). The thin vertical lines indicate 06:00 and 18:00 LT as an approximation for day- and nighttime. The dashed line in the top left panel shows the median height of the PBL top along air stream 3 (orange).

proximately $500 \mathrm{hPa}$ (approx. $318 \mathrm{~K}$ ), air stream 3 is lifted from the PBL before joining the pathway of air streams 1 and 2. The advection (air streams 1 and 2) and lifting (air stream 3) of air masses from the IGP to the TP is enabled by the large-scale forcing, i.e., the winds at $500 \mathrm{hPa}$ turning from northwesterly to southwesterly on 13 March (Fig. 8) and by local effects such as valley wind systems and updrafts due to heated mountain flanks.

We further analyzed the mean atmospheric stability calculated as the vertical gradient in equivalent potential temper- ature $\theta_{\mathrm{e}}$ in the presumed source region of air streams 1 and 2 in northern India from ERA-Interim reanalysis data (not shown). This analysis shows that the inflow of warm and dry air on 11 March associated with the above-mentioned ridge over northern India resulted in a strong decrease of the PBL height from about 3 to about $1 \mathrm{~km}$. Furthermore, this resulted in a relatively low stability above the PBL up to about $500 \mathrm{hPa}$. This suggests that vertical spreading of air pollutants up to heights of 5-6 km particularly on and after 11 March, 2 to 3 days before the beginning of the observed 


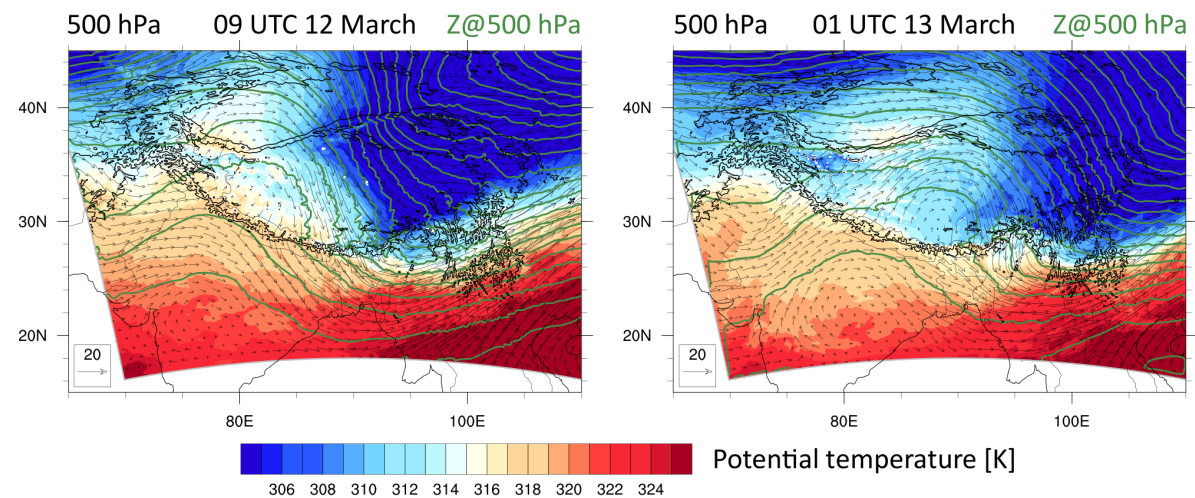

Figure 8. Geopotential height at $500 \mathrm{hPa}$ (green lines, contour intervals $250 \mathrm{~m}$ ) and potential temperature (colored, in K) at 09:00 UTC on 12 March 2009 (left panel) and 01:00 UTC on 13 March 2009 (right panel) from COSMO. Horizontal wind at 500 hPa is indicated with arrows (reference arrow $20 \mathrm{~ms}^{-1}$ ).
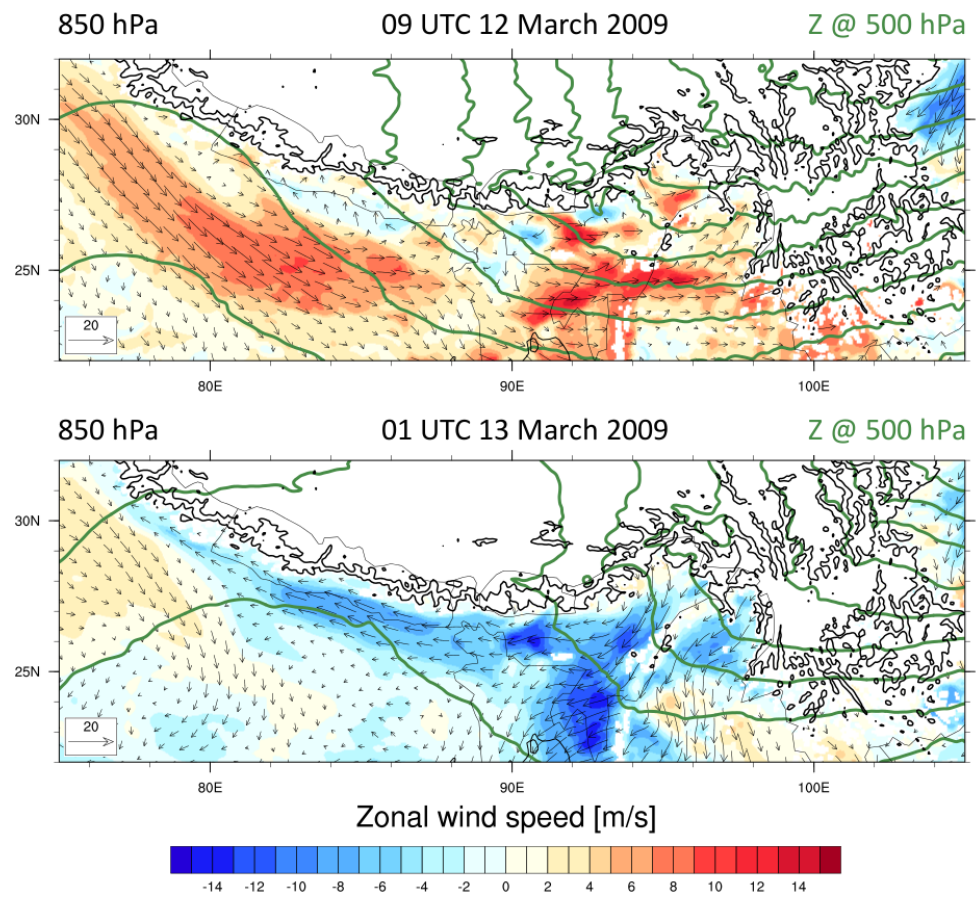

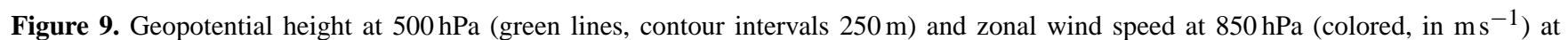
09:00 UTC on 12 March 2009 (top panel) and at 01:00 UTC on 13 March 2009 (bottom panel) from COSMO. Horizontal wind at 850 hPa is indicated with arrows (reference arrow $20 \mathrm{~ms}^{-1}$ ).

pollution event over the TP region, is plausible. Once reaching these altitudes, the air pollutants could then be transported to the Himalayas as discussed above for air streams 1 and 2. An exact quantification of the vertical diffusion of air pollutants over the source regions as well as the relative contribution of the synoptic forcing and local effects, however, would require additional model studies and is thus beyond the scope of the current analysis.

To summarize, the analysis of the backward trajectories presented in this section suggests that the source region of the plume is located southwest of the Himalayas and that the transport occurs predominantly along a relatively narrow band without much vertical motion. Some of the backward trajectories, however, also originate from lower altitudes (about $2000 \mathrm{~m}$ ) directly south of the Himalayas, indicating strong uplifting and the transport of polluted air from the PBL over the northern IGP up to the plateau. Major valleys seem to play an important role for this subset as the trajectories are channeled through them.

From the plume location, the polluted air is transported eastwards, which fits well to the remarkably high levels of fine-mode aerosols measured at Nam Co on the follow- 

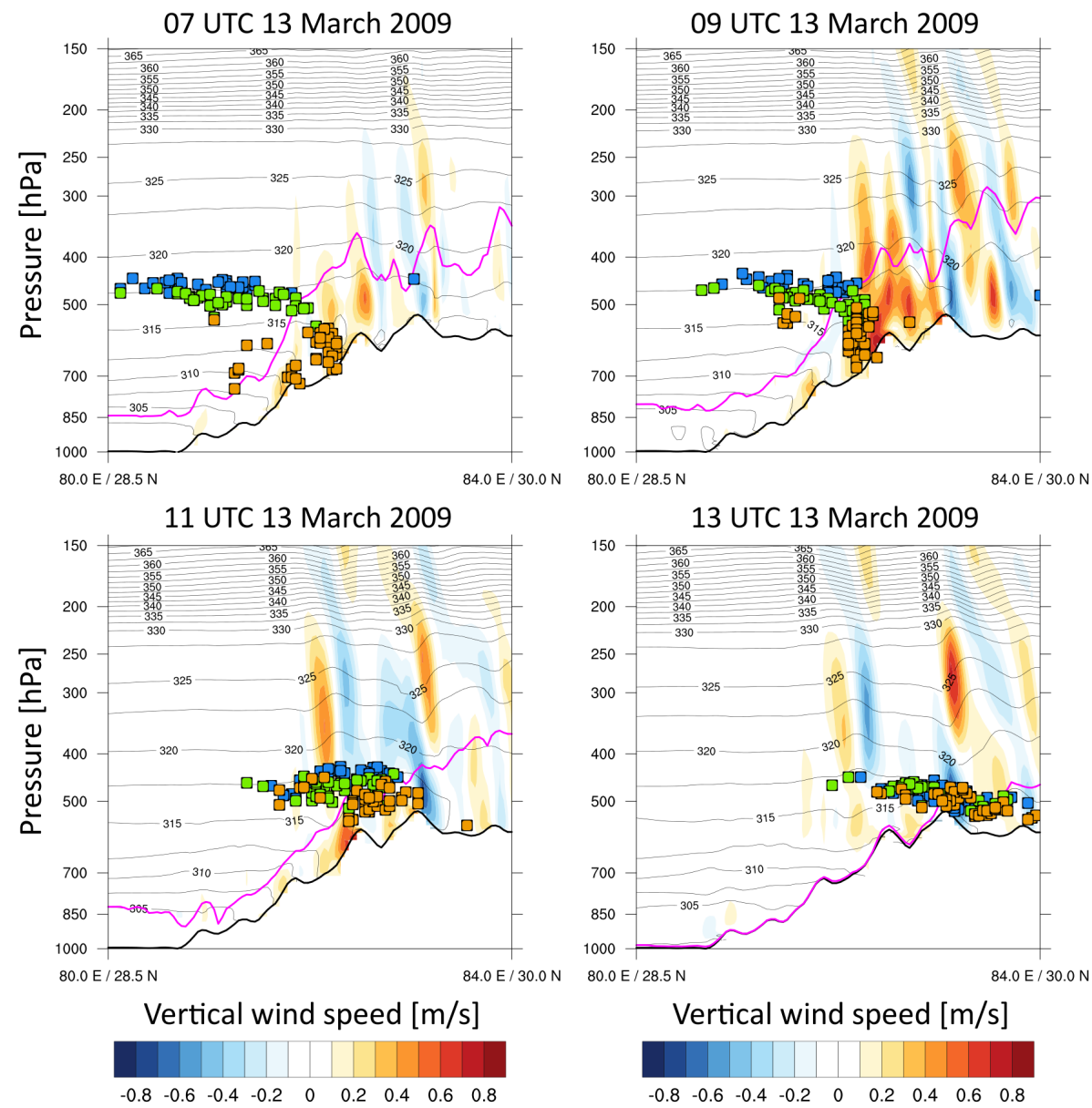

Figure 10. Vertical cross sections along the mean direction of transport (thick black line segment in Fig. 6b) at 07:00, 09:00, 11:00 and 13:00 UTC on 13 March 2009. Colored contours show vertical wind speed $\left(\mathrm{m} \mathrm{s}^{-1}\right)$, thin black lines are isentropes (K), thick black line is the surface, and the magenta line shows the PBL top as calculated by COSMO via a Bulk-Richardson number method. Trajectory positions are zonally projected onto the cross section. Blue, green and orange filled squares represent air stream 1, 2 and 3, respectively (cf. Fig. 6b).

ing day (14 March, see Fig. 2, data available from 01:00 to 07:00 UTC). This suggests that there is a direct connection between the CALIOP aerosol-rich air (plume) and the AERONET high FMF at Nam Co. Note the wide spread of heights of the trajectories in the vicinity of Nam Co, showing that the pollution is distributed throughout the whole troposphere, reaching levels of up to $10000 \mathrm{~m}$ a.s.l. This could potentially allow for mixing of pollution into the stratosphere during stratosphere-troposphere exchange events, particularly since the TP region is known to be a hot spot for such events (Škerlak et al., 2014).

\subsubsection{Nam Co}

Also for the $72 \mathrm{~h}$ backward trajectories arriving at Nam Co at 03:00 UTC on 16 March 2009, we identify three major air streams (see Fig. 11). We define air stream 1 (28 out of 121 trajectories) as the southwesterly flow which rises to heights of approximately 6000 ma.s.l. on 14 March. Air stream 2 consists of trajectories (54 out of 121) that are advected from the west and stay at altitudes of around $4500 \mathrm{~m}$ a.s.l. before following the pathway of air stream 1 over the TP. Air stream 3 originates in the PBL over the foothills of the Himalayas and is advected from the east (39 trajectories).

The basic motion of air parcels in air streams 1 and 2 can again be explained by the synoptic situation. The ridge present on 13 March weakens on 14 March (see Figs. 8 and 12) and a trough associated with the inflow of upper atmospheric cold air from Central Asia forms on the western side of the TP. This leads to westerly and southwesterly winds over northern (air stream 2) and central India (air stream 1), respectively. As the trough moves eastward on 14 March, the winds over much of India turn to a southwesterly direction such that both air streams 1 and 2 are now transported towards the Himalayas (see Figs. 11 and 12).

Parts of air stream 3 are advected from the east while other parts are trapped in the northern IGP and the adjacent valleys (Fig. 11b). We find that most air masses in this 

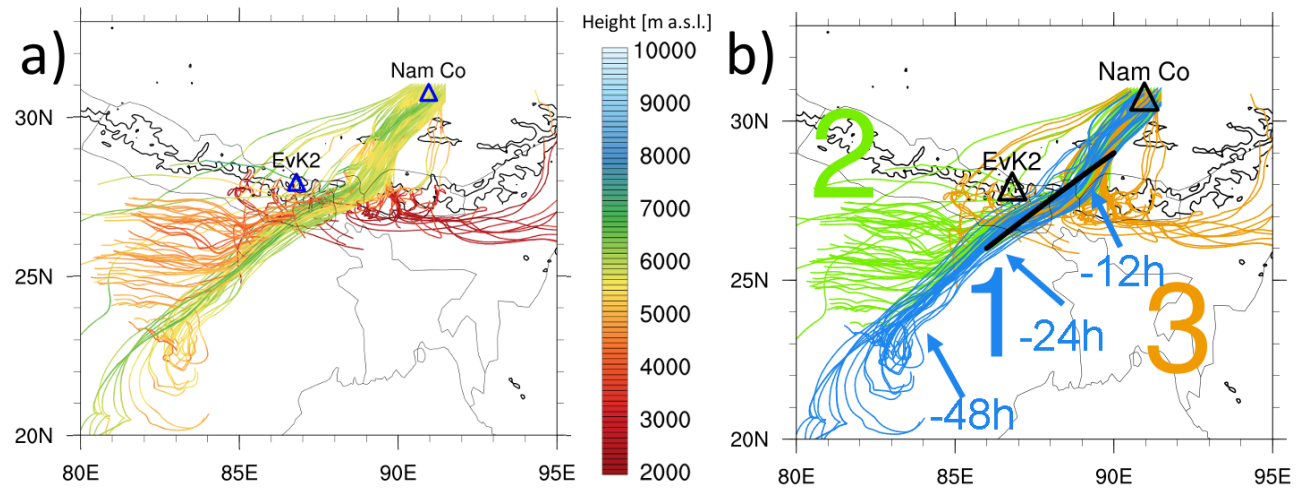

Figure 11. Trajectories (72 h backward) started near Nam Co (triangle) at 03:00 UTC on 16 March 2009 from an altitude of 5520 ma.s.1.. Black lines show orography (2000 and 4000 ma.s.l. contour lines), and the other triangle is EvK2 station. (a) Height along the trajectories, color coded (in $\mathrm{m}$ a.s.1.); (b) Trajectories classified into three air streams: (1) southwesterly flow rising to heights around 6000 ma.s.1., (2) advection from the west at heights around 4500 ma.s.l. and (3) trajectories originating in the PBL south of the Himalayas. The approximate location of air stream 1 is indicated for 12,24 and $48 \mathrm{~h}$ prior to reaching Nam Co.

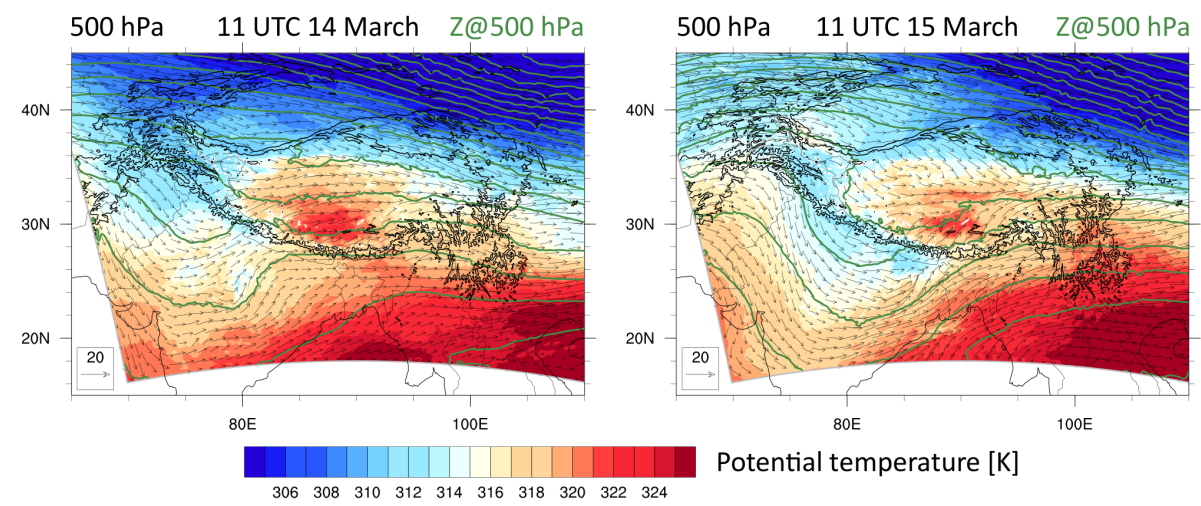

Figure 12. As Fig. 8 but at 11:00 UTC on 14 March 2009 (left panel) and 11:00 UTC on 15 March 2009 (right panel).

air stream reach the plateau via two main crossings: one is the Chumbi Valley between Sikkim, Bhutan and Tibet and the other one lies further to the east over central and eastern Bhutan. Since the adjacent southern regions are highly polluted (cf. Fig. 4a) and winds are generally weak at lower levels during this period, this indicates an effective transport pathway for pollution including absorbing aerosols. It is interesting to note that similar cross-mountain pathways were also observed in a study on trans-Himalayan flights of barheaded geese (Hawkes et al., 2011). On 15 March, the trough deepens and continues to move eastward, such that the winds at $500 \mathrm{hPa}$ turn southwesterly and increase in strength (right panel in Fig. 12). This, combined with the heated mountain flanks in the afternoon, helps to lift air stream 3 over the Himalayas and onto the TP. The BC data from EvK2 show extraordinary high values of up to $3800 \mathrm{ng} \mathrm{m}^{-3}$ at 17:00 local Nepal time on 15 March 2009, 1 day before the high AOD values were measured at Nam Co. This supports the finding from the back-trajectory calculations that these polluted air masses were transported from EvK2 and its surroundings to Nam Co in less than $24 \mathrm{~h}$.

From Fig. 13 it can be seen that air stream 3 is in the PBL most of the time (e.g., from the diurnal temperature variations and high humidity) whereas air streams 1 and 2 are only affected by slow cooling $\left(\theta\right.$ and $\left.\theta_{\mathrm{e}}\right)$. The uplifting of air stream 1 on 14 March can again be explained by northward motion on slanting isentropes in a baroclinic zone.

For both discussed sets of trajectories (plume and Nam Co), a significant amount air mass transport occurs at midtropospheric levels (around $500 \mathrm{hPa}$ ). This finding is in agreement with the study by Lawrence and Lelieveld (2010) who reported that there appears to be an effective pathway for transport of pollution from the IGP to the Himalayas between December and April, especially at elevated atmospheric layers. 


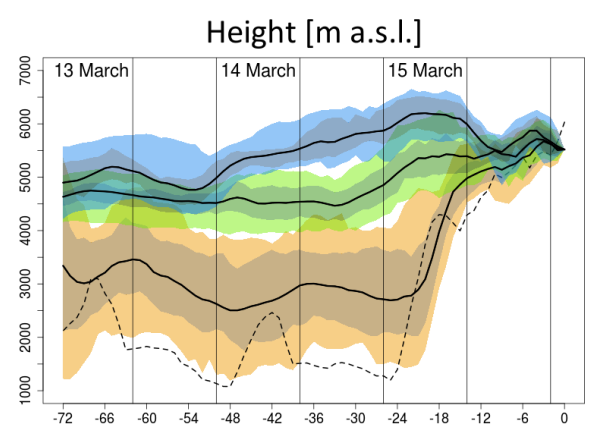

Potential temperature $[\mathrm{K}]$

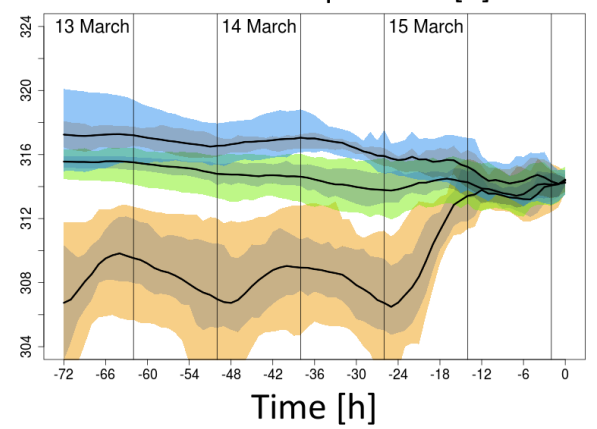

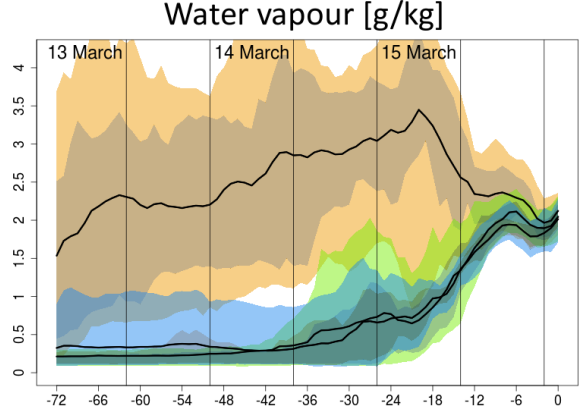

Equivalent potential temperature [K]

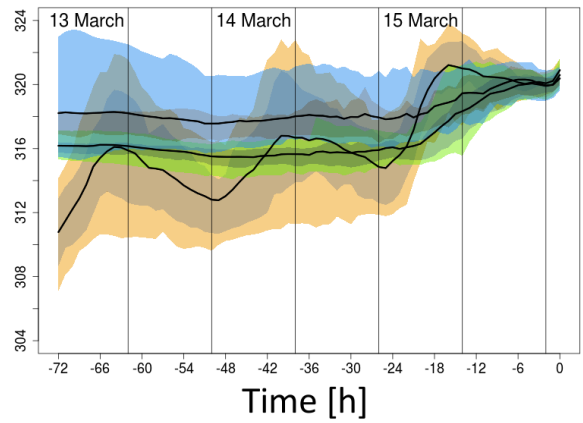

Figure 13. As Fig. 7 but for the $72 \mathrm{~h}$ backward trajectories started at 03:00 UTC on 16 March 2009 in the vicinity of Nam Co at $5520 \mathrm{~m}$ a.s.1. (cf. Fig. 11).

\section{Conclusions}

The combination of ground- and space-based remote sensing data together with in situ observations and high-resolution trajectory calculations enables a comprehensive assessment of possible transport pathways of polluted air masses found in ABCs into the remote and sensitive HTP area.

We investigate a severe pollution episode that occurred on the TP during 13-19 March 2009. This event was selected on the base of AERONET L2 data showing the maximum yearly AOD $500 \mathrm{~nm}$ of fine-mode aerosols at Nam Co station in central Tibet. It was also monitored simultaneously at EvK2 station in the high Khumbu Valley in Nepal and represents the most significant event of 2009.

Further AERONET sites located south of the Himalayas and in Thailand also retrieved very high fine-mode AOD $500 \mathrm{~nm}$ during the same time, which shows that this episode occurred on a large scale. This is further supported by OMI AAOD $500 \mathrm{~nm}$ data pointing out the presence of an atmospheric brown cloud with significant amounts of absorbing aerosols over South Asia during 13-19 March 2009. CALIOP high-resolution vertical profiles show aerosol layers "coating" the HTP with polluted air masses extending from the surface up to high tropospheric layers over southern Tibet.

Air mass trajectories are analyzed for severe pollution features observed on the TP during the case study using wind fields from the high-resolution numerical weather prediction model COSMO. The transport of pollution is found to oc- cur along several effective pathways from the IGP and the foothills of the Himalayas to all tropospheric levels over the TP. Approximately two-thirds of the analyzed air masses are advected to the TP quasi-isentropically at mid-tropospheric levels and one-third is lifted from the PBL south of the Himalayas.

The cross-Himalayan transport of pollution during this case study is enabled by the combination of local meteorological patterns such as updrafts near heated mountain flanks, valley wind systems, and large-scale forcing at midtropospheric levels. Weak zonal winds over the IGP and the Himalayan foothills support the accumulation of pollution in this region and relatively low stability above the PBL over the IGP permits for vertical spreading of air pollutants up to the middle troposphere. Finally, the inflow of cold air from higher latitudes leads to the formation of a trough, adding a southerly component to the winds at $500 \mathrm{hPa}$, carrying the polluted air masses onto the TP.

Overall, the analyses presented in this study provide an in-depth understanding of cross-Himalayan pollution advection reported in previous works. In particular, we find that $\mathrm{ABCs}$ and other polluted air masses from the southern side of the Himalayas can traverse the high mountain range not only through the major north-south river valleys but also by being lifted and advected over the Himalayas. Furthermore, we quantify the relative contribution of advection from mid-tropospheric levels over India and the PBL over the Himalayan foothills. 
The findings from the meteorological analysis could be used to put the presented case study into a climatological perspective, i.e., to quantify the frequency of such events, which is required to quantify the total impact of cross-Himalayan pollution transport on the HTP. Such an analysis could include the quantification of periods with the following characteristics: weak zonal winds at the southern side of the Himalayas and low stability above the PBL (up to about $500 \mathrm{hPa}$ ) over the IGP, as well as the passing of synoptic scale troughs over the TP followed by a southerly component of the $500 \mathrm{hPa}$ winds over the IGP.

Moreover, chemical transport models could be used to determine the contribution of specific sources to polluted air masses that cross the Himalayas. Further observational and modeling studies are thus urgently needed to identify the chemical speciation and the spatiotemporal distribution of pollutants in the HTP in order to investigate their climatic and environmental implications.

Because of the rapid and effective transport pathway onto the HTP, a reduction in anthropogenic aerosols such as BC would not only be beneficial for human health near the emission sources but it would also help to protect the sensitive environments on the Tibetan Plateau.

\section{The Supplement related to this article is available online at doi:10.5194/acp-15-6007-2015-supplement.}

Acknowledgements. This study was supported by the National Natural Science Foundation of China (41121001, 41225002), the Strategic Priority Research Program (B) of the Chinese Academy of Sciences (XDB03030504) and the project "A Sustainable Atmosphere for the Kathmandu Valley" SusKat at the Institute for Advanced Sustainability Studies (IASS), Germany. Our appreciation goes to the many colleagues who have shared their interest and constructive comments for this study, with our special thanks to A. Miltenberger. We thank B. Holben, G. P Gobbi, S. N. Tripathi, G. Leeuw, S. Verma, S. Janjai and their staff for establishing and maintaining the AERONET sites (Nam Co, EVK2-CNR, Kanpur, Pantnagar, Gual_Pahari, Kolkata and Chiang_Mai_Met_Sta). The CALIOP and OMI data were available from the Atmospheric Science Data Center. BC data from the Ev-K2-CNR SHARE station were generously provided by A. Marinoni. S.-W. Kim was supported by KMA R\&D (CATER 2012-3020) and by the Korean Ministry of Environment as "Climate Change Correspondence".

Edited by: Y. Cheng

\section{References}

Babu, S. S., Manoj, M., Moorthy, K. K., Gogoi, M. M., Nair, V. S., Kompalli, S. K., Satheesh, S., Niranjan, K., Ramagopal, K., and Bhuyan, P.: Trends in aerosol optical depth over Indian region:
Potential causes and impact indicators, J. Geophys. Res.-Atmos., 118, 11794-11806, doi:10.1002/2013JD020507, 2013.

Baldauf, M., Seifert, A., Förstner, J., Majewski, D., Raschendorfer, M., and Reinhardt, T.: Operational convective-scale numerical weather prediction with the COSMO Model: Description and sensitivities, Mon. Weather Rev., 139, 3887-3905, doi:10.1175/MWR-D-10-05013.1, 2011.

Bolch, T., Kulkarni, A., Kaab, A., Huggel, C., Paul, F., Cogley, J. G., Frey, H., Kargel, J. S., Fujita, K., Scheel, M., Bajracharya, S., and Stoffel, M.: The state and fate of Himalayan glaciers, Science, 336, 310-314, doi:10.1126/science.1215828, 2012.

Bonasoni, P., Laj, P., Marinoni, A., Sprenger, M., Angelini, F., Arduini, J., Bonafè, U., Calzolari, F., Colombo, T., Decesari, S., Di Biagio, C., di Sarra, A. G., Evangelisti, F., Duchi, R., Facchini, MC., Fuzzi, S., Gobbi, G. P., Maione, M., Panday, A., Roccato, F., Sellegri, K., Venzac, H., Verza, GP., Villani, P., Vuillermoz, E., and Cristofanelli, P.: Atmospheric Brown Clouds in the Himalayas: First two years of continuous observations at the Nepal Climate Observatory-Pyramid (5079 m), Atmos. Chem. Phys., 10, 7515-7531, doi:10.5194/acp-10-7515-2010, 2010.

Bond, T., Doherty, S., Fahey, D., Forster, P., Berntsen, T., DeAngelo, B., Flanner, M., Ghan, S., Kärcher, B., and Koch, D.: Bounding the role of black carbon in the climate system: A scientific assessment, J. Geophys. Res.-Atmos., 118, 5380-5552, doi:10.1002/jgrd.50171, 2013.

Cao, J., Tie, X., Xu, B., Zhao, Z., Zhu, C., Li, G., and Liu, S.: Measuring and modeling black carbon (BC) contamination in the SE Tibetan Plateau, J. Atmos. Chem., 67, 45-60, doi:10.1007/s10874-011-9202-5, 2011.

Cong, Z.: Individual particle analysis of atmospheric aerosols at Nam Co, Tibetan Plateau, Aerosol Air Qual. Res., 9, 323-331, doi:10.4209/aaqr.2008.12.0064, 2009.

Decesari, S., Facchini, M. C., Carbone, C., Giulianelli, L., Rinaldi, M., Finessi, E., Fuzzi, S., Marinoni, A., Cristofanelli, P., Duchi, R., Bonasoni, P., Vuillermoz, E., Cozic, J., Jaffrezo, J. L., and Laj, P.: Chemical composition of $\mathrm{PM}_{10}$ and $\mathrm{PM}_{1}$ at the highaltitude Himalayan station Nepal Climate Observatory-Pyramid (NCO-P) (5079 m a.s.1.), Atmos. Chem. Phys., 10, 4583-4596, doi:10.5194/acp-10-4583-2010, 2010.

Dee, D. P., Uppala, S. M., Simmons, A. J., Berrisford, P., Poli, P., Kobayashi, S., Andrae, U., Balmaseda, M. A., Balsamo, G., Bauer, P., Bechtold, P., Beljaars, A. C. M., van de Berg, L., Bidlot, J., Bormann, N., Delsol, C., Dragani, R., Fuentes, M., Geer, A. J., Haimberger, L., Healy, S. B., Hersbach, H., Holm, E. V., Isaksen, L., Kallberg, P., Köhler, M., Matricardi, M., McNally, A. P., Monge-Sanz, B. M., Morcette, J.-J., Park, B.-K., Peubey, C., de Rosnay, P., Tavolato, C., Thepaut, J.-N. and Vitart, F.: The ERA-Interim reanalysis: Configuration and performance of the data assimilation system, Q. J. Roy. Meteorol. Soc., 137, 553-597, doi:10.1002/qj.828, 2011.

Dey, S. and Di Girolamo, L.: A climatology of aerosol optical and microphysical properties over the Indian subcontinent from 9 years (2000-2008) of Multiangle Imaging Spectroradiometer (MISR) data, J. Geophys. Res., 115, D15204, doi:10.1029/2009jd013395, 2010.

Dubovik, O. and King, M. D.: A flexible inversion algorithm for retrieval of aerosol optical properties from Sun and sky radiance measurements, J. Geophys. Res.-Atmos., 105, 20673-20696, doi:10.1029/2000JD900282, 2000. 
Dubovik, O., Smirnov, A., Holben, B., King, M., Kaufman, Y., Eck, T., and Slutsker, I.: Accuracy assessments of aerosol optical properties retrieved from Aerosol Robotic Network (AERONET) Sun and sky radiance measurements, J. Geophys. Res.-Atmos., 105, 9791-9806, doi:10.1029/2000JD900040, 2000.

Eck, T. F., Holben, B. N., Reid, J. S., Dubovik, O., Smirnov, A., O'Neill, N. T., Slutsker, I., and Kinne, S.: Wavelength dependence of the optical depth of biomass burning, urban, and desert dust aerosols, J. Geophys. Res.-Atmos., 104, 31333-31349, doi:10.1029/1999jd900923, 1999.

Eck, T., Holben, B., Sinyuk, A., Pinker, R., Goloub, P., Chen, H., Chatenet, B., Li, Z., Singh, R., and Tripathi, S.: Climatological aspects of the optical properties of fine/coarse mode aerosol mixtures, J. Geophys. Res.-Atmos., 115, D19205, doi:10.1029/2010JD014002, 2010.

Engling, G. and Gelencser, A.: Atmospheric brown clouds: From local air pollution to climate change, Elements, 6, 223-228, doi:10.2113/gselements.6.4.223, 2010.

Engling, G., Zhang, Y.-N., Chan, C.-Y., Sang, X.-F., Lin, M., Ho, K.-F., Li, Y.-S., Lin, C.-Y., and Lee, J. J.: Characterization and sources of aerosol particles over the southeastern Tibetan Plateau during the Southeast Asia biomass-burning season, Tellus B, 63, 117-128, doi:10.1111/j.1600-0889.2010.00512.x, 2011.

Flanner, M. G., Zender, C. S., Randerson, J. T., and Rasch, P. J.: Present-day climate forcing and response from black carbon in snow, J. Geophys. Res., 112, D11202, doi:10.1029/2006JD008003, 2007.

Fleming, Z. L., Monks, P. S., and Manning, A. J.: Review: Untangling the influence of air-mass history in interpreting observed atmospheric composition, Atmos. Res., 104, 1-39, doi:10.1016/j.atmosres.2011.09.009, 2012.

Gautam, R., Hsu, N. C., and Lau, K. M.: Premonsoon aerosol characterization and radiative effects over the Indo-Gangetic Plains: Implications for regional climate warming, J. Geophys. Res., 115, D17208, doi:10.1029/2010jd013819, 2010.

Gautam, R., Hsu, N. C., Tsay, S. C., Lau, K. M., Holben, B., Bell, S., Smirnov, A., Li, C., Hansell, R., Ji, Q., Payra, S., Aryal, D., Kayastha, R., and Kim, K. M.: Accumulation of aerosols over the Indo-Gangetic plains and southern slopes of the Himalayas: Distribution, properties and radiative effects during the 2009 pre-monsoon season, Atmos. Chem. Phys., 11, 12841-12863, doi:10.5194/acp-11-12841-2011, 2011.

Hawkes, L. A., Balachandran, S., Batbayar, N., Butler, P. J., Frappell, P. B., Milsom, W. K., Tseveenmyadag, N., Newman, S. H., Scott, G. R., Sathiyaselvam, P., Takekawa, J. Y., Wikelski, M., and Bishop, C. M.: The trans-Himalayan flights of bar-headed geese (Anser indicus), P. Natl. Acad. Sci. USA, 108, 9516-9519, doi:10.1073/pnas.1017295108, 2011.

Holben, B., Eck, T., Slutsker, I., Tanre, D., Buis, J., Setzer, A., Vermote, E., Reagan, J., Kaufman, Y., and Nakajima, T.: AERONET - A federated instrument network and data archive for aerosol characterization, Remote Sens. Environ., 66, 1-16, doi:10.1016/S0034-4257(98)00031-5, 1998.

Immerzeel, W. W., van Beek, L. P., and Bierkens, M. F.: Climate change will affect the Asian water towers, Science, 328, 13821385, doi:10.1126/science.1183188, 2010.
Jacobson, M. Z.: Strong radiative heating due to the mixing state of black carbon in atmospheric aerosols, Nature, 409, 695-697, doi:10.1038/35055518, 2001.

Kang, S., Xu, Y., You, Q., Flügel, W.-A., Pepin, N., and Yao, T.: Review of climate and cryospheric change in the Tibetan Plateau, Environ. Res. Lett., 5, 015101, doi:10.1088/1748 9326/5/1/015101, 2010.

Kaspari, S. D., Schwikowski, M., Gysel, M., Flanner, M. G., Kang, S., Hou, S., and Mayewski, P. A.: Recent increase in black carbon concentrations from a Mt. Everest ice core spanning 1860-2000 AD, Geophys. Res. Lett., 38, L04703, doi:10.1029/2010g1046096, 2011.

Kehrwald, N. M., Thompson, L. G., Tandong, Y., MosleyThompson, E., Schotterer, U., Alfimov, V., Beer, J., Eikenberg, J., and Davis, M. E.: Mass loss on Himalayan glacier endangers water resources, Geophys. Res. Lett., 35, L22503, doi:10.1029/2008GL035556, 2008.

Kopacz, M., Mauzerall, D. L., Wang, J., Leibensperger, E. M., Henze, D. K., and Singh, K.: Origin and radiative forcing of black carbon transported to the Himalayas and Tibetan Plateau, Atmos. Chem. Phys., 11, 2837-2852, doi:10.5194/acp-11-28372011, 2011.

Lau, W. K. M., Kim, M.-K., Kim, K.-M., and Lee, W.-S.: Enhanced surface warming and accelerated snow melt in the Himalayas and Tibetan Plateau induced by absorbing aerosols, Environ. Res. Lett., 5, 025204, doi:10.1088/1748-9326/5/2/025204, 2010.

Lawrence, M. G. and Lelieveld, J.: Atmospheric pollutant outflow from southern Asia: A review, Atmos. Chem. Phys., 10, 1101711096, doi:10.5194/acp-10-11017-2010, 2010.

Lu, Z., Streets, D. G., Zhang, Q., and Wang, S.: A novel backtrajectory analysis of the origin of black carbon transported to the Himalayas and Tibetan Plateau during 1996-2010, Geophys. Res. Lett., 39, L01809, doi:10.1029/2011g1049903, 2012.

Ma, Y., Wang, Y., Wu, R., Hu, Z., Yang, K., Li, M., Ma, W., Zhong, L., Sun, F., Chen, X., Zhu, Z., Wang, S., and Ishikawa, H.: Recent advances on the study of atmosphere-land interaction observations on the Tibetan Plateau, Hydrol. Earth Syst. Sci., 13, 1103-1111, doi:10.5194/hess-13-1103-2009, 2009.

Marenco, F., Amiridis, V., Marinou, E., Tsekeri, A., and Pelon, J.: Airborne verification of CALIPSO products over the Amazon: a case study of daytime observations in a complex atmospheric scene, Atmos. Chem. Phys., 14, 11871-11881, doi:10.5194/acp14-11871-2014, 2014.

Marinoni, A., Cristofanelli, P., Laj, P., Duchi, R., Calzolari, F., Decesari, S., Sellegri, K., Vuillermoz, E., Verza, G. P., Villani, P., and Bonasoni, P.: Aerosol mass and black carbon concentrations, a two year record at NCO-P (5079 m, Southern Himalayas), Atmos. Chem. Phys., 10, 8551-8562, doi:10.5194/acp-10-85512010, 2010.

Marinoni, A., Cristofanelli, P., Laj, P., Duchi, R., Putero, D., Calzolari, F., Landi, T. C., Vuillermoz, E., Maione, M., and Bonasoni, P.: High black carbon and ozone concentrations during pollution transport in the Himalayas: Five years of continuous observations at NCO-P global GAW station, J. Environ. Sci.-China, 25, 1618-1625, doi:10.1016/S1001-0742(12)60242-3, 2013.

Ming, J., Wang, P., Zhao, S., and Chen, P.: Disturbance of light-absorbing aerosols on the albedo in a winter snowpack of Central Tibet, J. Environ. Sci.-China, 25, 1601-1607, doi:10.1016/s1001-0742(12)60220-4, 2013. 
O'Neill, N. T.: Spectral discrimination of coarse and fine mode optical depth, J. Geophys. Res., 108, 4559, doi:10.1029/2002jd002975, 2003.

O’Neill, N. T., Pancrati, O., Baibakov, K., Eloranta, E., Batchelor, R. L., Freemantle, J., McArthur, L. J. B., Strong, K., and Lindenmaier, R.: Occurrence of weak, submicron, tropospheric aerosol events at high Arctic latitudes, Geophys. Res. Lett., 35, L14814, doi:10.1029/2008GL033733, 2008.

Prabha, T. V., Karipot, A., Axisa, D., Kumari, B. P., Maheskumar, R. S., Konwar, M., Kulkarni, J. R., and Goswami, B. N.: Scale interactions near the foothills of Himalayas during CAIPEEX, J. Geophys. Res.-Atmos., 117, D10203, doi:10.1029/2011jd016754, 2012.

Qian, Y., Flanner, M. G., Leung, L. R., and Wang, W.: Sensitivity studies on the impacts of Tibetan Plateau snowpack pollution on the Asian hydrological cycle and monsoon climate, Atmos. Chem. Phys., 11, 1929-1948, doi:10.5194/acp-11-19292011, 2011.

Ramanathan, V. and Carmichael, G.: Global and regional climate changes due to black carbon, Nat. Geosci., 1, 221-227, doi:10.1038/ngeo156, 2008.

Ramanathan, V., Li, F., Ramana, M. V., Praveen, P. S., Kim, D., Corrigan, C. E., Nguyen, H., Stone, E. A., Schauer, J. J., Carmichael, G. R., Adhikary, B., and Yoon, S. C.: Atmospheric brown clouds: Hemispherical and regional variations in longrange transport, absorption, and radiative forcing, J. Geophys. Res., 112, D22S21, doi:10.1029/2006jd008124, 2007a.

Ramanathan, V., Ramana, M. V., Roberts, G., Kim, D., Corrigan, C., Chung, C., and Winker, D.: Warming trends in Asia amplified by brown cloud solar absorption, Nature, 448, 575-578, doi:10.1038/nature06019, 2007b.

Škerlak, B., Sprenger, M., and Wernli, H.: A global climatology of stratosphere-troposphere exchange using the ERA-Interim data set from 1979 to 2011, Atmos. Chem. Phys., 14, 913-937, doi:10.5194/acp-14-913-2014, 2014.

Smirnov, A., Holben, B., Eck, T., Dubovik, O., and Slutsker, I.: Cloud-screening and quality control algorithms for the AERONET database, Remote Sens. Environ., 73, 337-349, doi:10.1016/S0034-4257(00)00109-7, 2000.
Thompson, L. G., Yao, T., Mosley-Thompson, E., Davis, M., Henderson, K., and Lin, P.-N.: A high-resolution millennial record of the South Asian monsoon from Himalayan ice cores, Science, 289, 1916-1919, doi:10.1126/science.289.5486.1916, 2000.

Torres, O., Tanskanen, A., Veihelmann, B., Ahn, C., Braak, R., Bhartia, P. K., Veefkind, P., and Levelt, P.: Aerosols and surface UV products from Ozone Monitoring Instrument observations: An overview, J. Geophys. Res.-Atmos., 112, D24S47, doi:10.1029/2007JD008809, 2007.

Wernli, B. H. and Davies, H. C.: A Lagrangian-based analysis of extratropical cyclones, I: The method and some applications, Q. J. Roy. Meteorol. Soc., 123, 467-489, doi:10.1002/qj.49712353811, 1997.

Winker, D. M., Vaughan, M. A., Omar, A., Hu, Y., Powell, K. A., Liu, Z., Hunt, W. H., and Young, S. A.: Overview of the CALIPSO mission and CALIOP data processing algorithms, J. Atmos. Ocean. Tech., 26, 2310-2323, doi:10.1175/2009JTECHA1281.1, 2009.

Xia, X., Zong, X., Cong, Z., Chen, H., Kang, S., and Wang, P.: Baseline continental aerosol over the central Tibetan plateau and a case study of aerosol transport from South Asia, Atmos. Environ., 45, 7370-7378, doi:10.1016/j.atmosenv.2011.07.067, 2011.

Xu, B., Cao, J., Hansen, J., Yao, T., Joswia, D. R., Wang, N., Wu, G., Wang, M., Zhao, H., Yang, W., Liu, X., and He, J.: Black soot and the survival of Tibetan glaciers, P. Natl. Acad. Sci. USA, 106, 22114-22118, doi:10.1073/pnas.0910444106, 2009.

Yao, T., Thompson, L., Yang, W., Yu, W., Gao, Y., Guo, X., Yang, X., Duan, K., Zhao, H., and Xu, B.: Different glacier status with atmospheric circulations in Tibetan Plateau and surroundings, Nat. Clim. Change, 2, 663-667, doi:10.1038/nclimate1580, 2012.

Ye, D.-Z. and Wu, G.-X.: The role of the heat source of the Tibetan Plateau in the general circulation, Meteorol. Atmos. Phys., 67, 181-198, 1998.

Zhao, S., Ming, J., Sun, J., and Xiao, C.: Observation of carbonaceous aerosols during 2006-2009 in Nyainqentanglha Mountains and the implications for glaciers, Environ. Sci. Pollut. Res. Int., 20, 5827-5838, doi:10.1007/s11356-013-1548-6, 2013. 